\title{
メカニカル・グライディング法で作成した非晶質 $\mathrm{Cu}_{50} \mathrm{Ti}_{50}$ 合金の結晶化
}

\author{
中村邦康* 笠井清史** 南雲道彦***
}

J. Japan Inst. Metals, Vol. 54, No. 12 (1990), pp. 1320-1328

Crystallization Kinetics of Amorphous $\mathrm{Cu}_{50} \mathrm{Ti}_{50}$ Alloy Prepared by Mechanical Grinding

Kuniyasu Nakamura*, Kiyoshi Kasai** and Michihiko Nagumo***

Crystallization kinetics of amorphous $\mathrm{Cu}_{50} \mathrm{Ti}_{50}$ alloy prepared by mechanical grinding of the intermetallic compound powder with a high energy ball mill was studied. Kinetics at the isothermal annealing was well analyzed in terms of the Johnson-Mehl-Avrami equation, giving a velocity exponent of 0.85 and an activation energy of $183 \mathrm{~kJ} / \mathrm{mol}$. Both figures are less than the corresponding values of the material prepared by a rapid cooling process. Kinetics at the athermal annealing was analyzed using the Kissinger method and an activation energy of $154 \mathrm{~kJ} / \mathrm{mol}$ was obtained in accord with the analysis with the JMA equation.

The amorphous state and the crystallization process were discussed from these results. In an amorphous material prepared by mechanical grinding, the crystalline fraction remains and is likely to act as nuclei of crystallization. Crystallization is likely to proceed two-dimensionally on these nuclei. The number and average size of nuclei were estimated to be $10^{24} / \mathrm{m}^{3}$ and of $10^{3}$ unit cells of $\mathrm{Cu}_{50} \mathrm{Ti}_{50}$, respectively.

The activation energy of diffusion estimated by assuming the two-dimensional crystal growth kinetics is $214 \mathrm{~kJ} / \mathrm{mol}$ and the diffusion of Ti atoms is likely to be rate-controlling. Atom migration necessary for the crystallization is considered to take place in a short range of the order of $5-10 \mathrm{~nm}$.

(Received August 17, 1990)

Keywords: amorphous alloy, mechanical grinding, solid state reaction, crystallization kinetics, diffusion

\section{I ，序言}

非晶質合金は結晶質合金と比べて高強度，高電気抵抗な どの新しい特性を有する材料として注目されている。しか し非平衡状態の物質であるため, ある温度以上では結晶化 しその性質は消滅する。この意味から非晶質の結晶化につ いて十分に研究されねばならない。また, 非晶質状態は一 義的に定めることが困難であり, 作成法によって構造や性 質が異なる。この点で結晶化過程を調べることは非晶質の 状態を評価する 1 つの方法としても重要である.

また通常の方法では合金化しにくい系を非晶質合金とし て得ることも可能であり,この結晶化によって安定な組織 が得られる.この場合にも結晶化過程は組織の微細さや均 一性に関して大きな影響を持つ、本研究は非晶質合金を等 温および非等温的に結晶化させ，その機構と結晶化の活性
化エネルギーを用いて非晶質の状態について情報を得るこ とを試みたものである。

非晶質の等温における結晶化の進行は核生成と成長を包 含した Johnson-Mehl-Avrami の式(1)

$$
X=1-\exp \left(-k t^{n}\right)
$$

で整理されることが多い.ここで $k$ は速度定数, $n$ は結晶 化機構により決まる指数である. 非晶質の結晶化について この式からその進行過程を求めた報告は多く、さまざまな 結果を得ている. Baburaj ら(2) $\mathrm{Fe}_{67} \mathrm{Co}_{18} \mathrm{SiB}_{14}$ で示差走 査熱分析(DSC) において 2 つ発熱ピークを認め, 結晶 化に 2 つの段階が存在するとした。すなわち第 1 ピーク で $n=2.0$ を得て一定の核生成速度, 拡散律速による初晶 $\alpha-\mathrm{Fe}$ の晶出, 第 2 ピークで $n=2.8$ を得て $(\mathrm{FeCo})_{3}(\mathrm{SiB})$ が界面に氺いて成長するとしている.

このよらと結晶化が多段階に渡るものとしてはConde ら (3) ${ }^{\left(2 \mathrm{Ni}_{68.5}\right.} \mathrm{Cr}_{14.5} \mathrm{P}_{17}$ でDSC における2つの発熱ピーク

* 早稲田大学大学院生 (Graduate Student, Waseda University, Tokyo)

** 早稲田大学大学院生, 現在 : NHK (Graduate Student, Waseda University, Tokyo. Present address: NHK, Tokyo)

*** 早稲田大学材料技術研究所 (Laboratory of Materials Science and Technology, Waseda University, Tokyo) 
を観察し，第 1 ピークにおいて指数として $2.4<n<2.6$ を 得て一定の核生成速度と 3 次元の拡散による $\mathrm{Ni}-\mathrm{Cr}$ の成 長を，第 2 ピークで $3.9<n<4.1$ を得て一定の核生成速度 と界面における $(\mathrm{NiCr})_{3} \mathrm{P}$ の 3 次元の成長が起こるといら 結果を得ている。 また， Kim ら ${ }^{(4)}$ は $\mathrm{Fe}_{100-x} \mathrm{~B}_{x}$ においての 結晶化過程で式 (1)に基づくプロットで結晶化の前半と 後半で指数 $n$ が変わるといら結果を得ている. $\mathrm{Cu}_{100-x} \mathrm{Ti}_{x}$ において Hwang ら (5) は指数 $1.07<n<2.04$ を得て結晶化 の律速機構は拡散によるとしている.

このよらにJMAの式で結晶化機構を解析する場合には 結晶化率の時間変化から求められた指数 $n$ で結晶化の機 構が推定されるといら利点があるが，式の適用性に問題が あればこの解析は意味を持たなくなる．結晶化相の析出の 様子が直接観察でされば解析を裏付けることは可能である が，実験的には困難が大きい.したがって JMA の式によ る解析に加えて, その他の解析により結晶化機構を吟味す ることが大切である. 本研究においてはJMA の解析結果 と平行してさまざまな解析を加えることにより, 結晶化機 構を考察してみた。

また，以上にみるように結晶化の形態は合金系によって その特徵が変わってきており，非晶質の作成条件によって も違ってくることが予想できる. 上に述べた結果はすべて 急冷法によって作成された試料についての結果であり，今 日注目されているメカニカル・アロイングで作成された非 晶質合金について結晶化機構を求めている報告はあまりな い.とこで我々はボールミルを用いた非晶質化の方法とし てメカニカル・グライディング法(以下 MG 法と略す) で 非晶質試料を作成して急冷法における結果と比較すること にした．特にMG 法で作成した試料の結晶化では試料中 に残存する結晶質部分が結晶核となり結晶化するといら報 告(6)があり，この点については十分に考察してみた.

\section{II. 実 験 方 法}

試料は市販の純度 $99.9 \%$ 金属間化合物 $\mathrm{Cu}_{50} \mathrm{Ti}_{50}$ 粉末 (ー20メッシュ)を原料とし，日新技研製振動型ボールミ ルスーパーミス $=$ NV-MA8を用いてグライディングを 行なった. 振動数は $13.3 \mathrm{~Hz}$, 容器水冷(流量 $1.68 \times 10^{-1}$ $\left.\mathrm{m}^{3} / \mathrm{h}\right), \mathrm{Ar}$ 雾囲気で行ないミリング時間は $160 \mathrm{~h}$ とした. ボールと試料との質量化は $6: 1$ とした。ボール径は 11 $\mathrm{mm}$ である。結晶化の進行は示差走査熱分析(DSC) で測 定し，島津製作所製 DSC-50を用いた。昇温速度は通常 $40 \mathrm{~K} / \mathrm{min}$ としたが，連続昇温に打ける結晶化の活性化エ ネルギーを求める場合には昇温速度を $10 \sim 40 \mathrm{~K} / \mathrm{min}$ の範 囲で変化させた. 我々は結晶化ピーク温度 $T_{\mathrm{x}}$ の経時变化

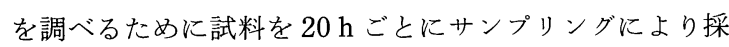
取し熱分析を行なった． $T_{\mathrm{x}}$ はミリング時間とともに上昇 し $600 \mathrm{~h}$ 程度の長時間ミリングによりほぼ $820 \mathrm{~K}$ で飽和 した． $T_{\mathrm{x}}$ を文献值と比較したものを Table 1 に示した。
Table 1 Comparison of crystallization peak temperature $T_{\mathrm{x}}$ of $\mathrm{Cu}$-Ti alloys.

\begin{tabular}{|c|c|c|c|c|}
\hline Composition & Process & $T_{\mathrm{x}} / \mathrm{K}$ & $\underset{\mathrm{K} / \mathrm{min}}{\text { Heating rate, }}$ & Reference \\
\hline $\mathrm{Cu}_{50} \mathrm{Ti}_{50}$ & MG & 600 & 10 & present study \\
\hline $\mathrm{Cu}_{50} \mathrm{Ti}_{50}$ & $\mathrm{RQ}$ & 623 & $2-3$ & (5) \\
\hline $\mathrm{Cu}_{50} \mathrm{Ti}_{50}$ & $\mathrm{RQ}$ & 701 & - & (11) \\
\hline $\mathrm{Cu}_{50} \mathrm{Ti}_{50}$ & $\mathrm{RQ}$ & $\begin{array}{c}691 \\
\text { (1st peak) } \\
715 \\
\text { (2nd peak) }\end{array}$ & 20 & (10) \\
\hline $\mathrm{Cu}_{43} \mathrm{Ti}_{57}$ & MA & 670 & 40 & (19) \\
\hline $\mathrm{Cu}_{43} \mathrm{Ti}_{57}$ & $\mathrm{RQ}$ & 649 & 40 & (19) \\
\hline
\end{tabular}

今回作成した $160 \mathrm{~h}$ のミリング材では $T_{\mathrm{x}}$ はやや低めであ った. すなわち $160 \mathrm{~h}$ のミリング材は非晶質化の進行段階 にあるものであると思われる。

$\mathrm{X}$ 線回折には理学電機社の RAD-C を用い,ターゲット を $\mathrm{Cu}$, チューブ電圧を $30 \mathrm{kV}$ ，チューブ電流を $40 \mathrm{~mA}$ と して測定した．原材料， $160 \mathrm{~h}$ ミリングした試料および結 晶化後の試料の X 線回折を Fig. 1 に示した. ミリング後 の試料はハローパターンを示しており，非晶質状態にあ る.またDSCによる分析結果はFig. 2 に示すように約 $600 \mathrm{~K}$ に発熱ピークを持ち結晶化の発熱量は $4.82 \mathrm{~kJ} / \mathrm{mol}$ であった．結晶化の発熱量としては結晶化開始温度から結 晶化終了温度までの DSC 曲線が曲む面積とした。

我々は先の研究(7) において $\mathrm{Cu}_{50} \mathrm{Ti}_{50}$ の $\mathrm{MG}$ でミリング 初期において Fig. 3 に示すような 2 つの発熱ピークを認 め,そしてこの $2 つ の$ 発熱ピークは長時間ミリング $(120$ $\mathrm{h}$ 以上) で合体し， $\mathrm{Cu}_{50} \mathrm{Ti}_{50}$ の結晶化のみが起こることを 認めた，そのためにミリング時間を $160 \mathrm{~h}$ とし，非晶質化

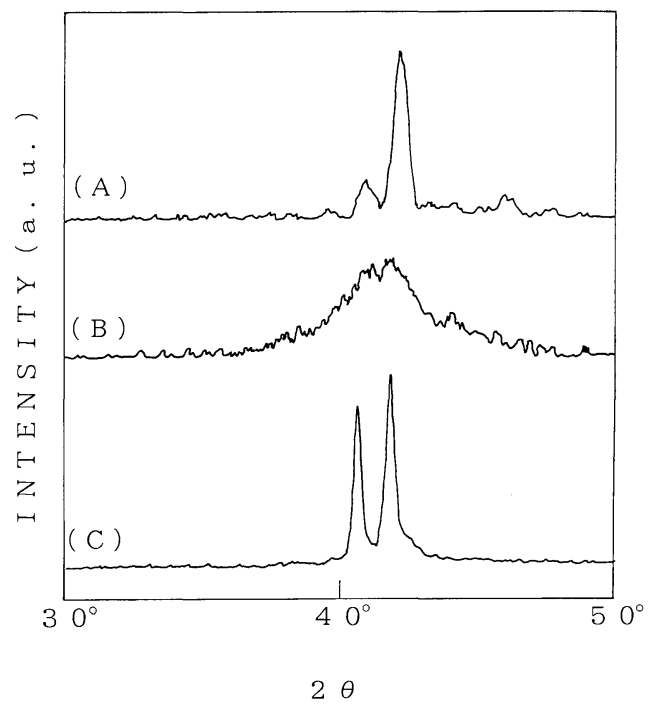

Fig. 1 X-ray diffraction patterns of (A) starting material, (B) after milling $160 \mathrm{~h}$, (C) heated up to $873 \mathrm{~K}$ with heating rate of $10 \mathrm{~K} / \mathrm{min}$. 


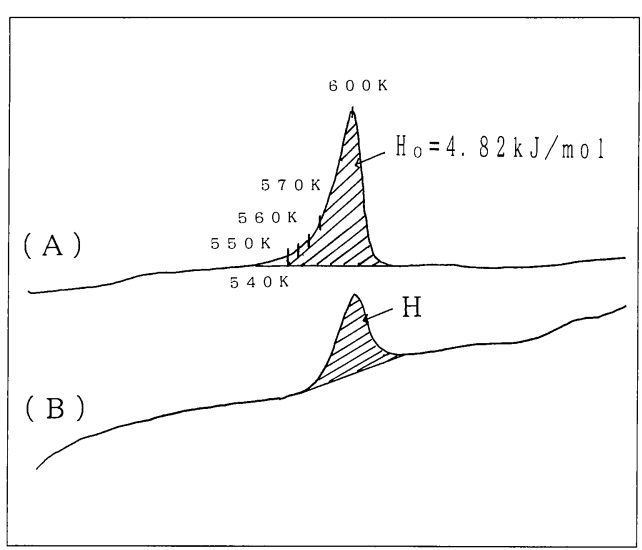

Fig. 2 Schematic record of a DSC curve of (A) showing temperatures for isothermal holding (B) heated up to $873 \mathrm{~K}$ with heating rate $10 \mathrm{~K} / \mathrm{min}$ after $4 \mathrm{~h}$ isothermal holding at $540 \mathrm{~K}$.

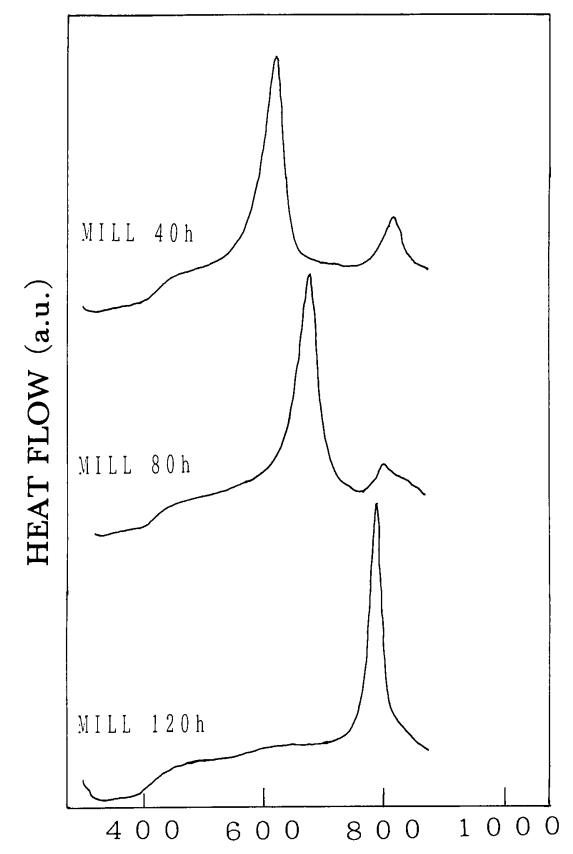

TEMPERATURE, $T / \mathrm{K}$

Fig. 3 DSC curve of $\mathrm{Cu}_{50} \mathrm{Ti}_{50}$ alloy mechanically grind for $40,80,120 \mathrm{~h}$.

の進行段階にある非晶質 $\mathrm{Cu}_{50} \mathrm{Ti}_{50}$ の結晶化を追らことに した。

結晶化の kinetics を求めるために結晶化開始温度(約 $550 \mathrm{~K})$ 前後で $10 \mathrm{~K}$ きざみに $540 \mathrm{~K}$ から $570 \mathrm{~K}$ までを等 温保持温度 $T_{\mathrm{a}}$ に選び，その温度で等温保持して非晶質を 部分的に結晶化させた．その時の昇温プログラムを Fig. 4 亿示した。すなわち， $10 \mathrm{~K} / \mathrm{min}$ で等温保持温度まで昇 温し時間 $t$ 保持後自然冷却し, 再び $10 \mathrm{~K} / \mathrm{min}$ で $873 \mathrm{~K}$ ま

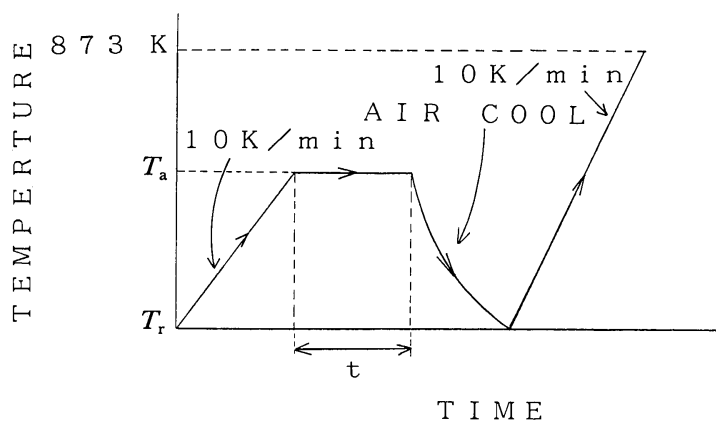

Fig. 4 Temperature diagram of partial crystallization.

で昇温して結晶化の発熱量を測定した。

透過型電子顕微鏡 (TEM)の観察には日立製作所製 HU$11 \mathrm{D}$ を用いて30万倍の透過像および制限視野電子線回折 像を撮影した。

\section{III. 実 験 結 果}

\section{1. 等温保持による結晶化}

結晶化による生成物は Fig. 1 および Table 2 に示すよ らにX 線回折の同定から $\mathrm{Cu}_{50} \mathrm{Ti}_{50}$ のみであった。しかし Table 2 に示したように固溶および歪によるものと思われ る面間隔 $d$ のシフトが生じている.

時間 $t$ を変化させその時の結晶化率を追えば kinetics を 求めることができる．保持していない試料および保持後の 試料の発熱量をそれぞれ $H_{0}, H$ とすれば， $H / H_{0}$ は未結晶 化率を表わすので結晶化率 $x$ は

$$
x=1-H / H_{0}
$$

で与えられる。

各等温保持温度に护ける結晶化率 $x$ の保持時間 $t$ 亿対す る変化を Fig. 5 に示す．結晶化率 $x$ を保持時間 $t$ の関数 として，JMAの式(1)で整理する. 式(1)に基づき $\ln t$ に対して $\ln [-\ln (1-x)]$ をプロットした結果を Fig. 6 に示した。得られた結果の直線性はよく，傾きおよび切片 から求まった $n$ 打よび $\ln k$ を Table 3 に示した。指数 $n$ は 0.85 となった。

速度定数 $k$ は Arrhenius 型の温度依存性,

$$
k=k_{0} \exp (-E / R T)
$$

Table 2 Diffraction angle $2 \theta$ and $d$-spacing.

\begin{tabular}{l|c|c||c|c}
\hline & $2 \theta$ & $d / \mathrm{nm}$ & $2 \theta$ & $d / \mathrm{nm}$ \\
\hline $\mathrm{Cu}_{50} \mathrm{Ti}_{50}$ (A.S.T.M.) & $41.1^{\circ}$ & 0.2194 & $42.3^{\circ}$ & 0.2133 \\
\hline Starting material & $40.92^{\circ}$ & 0.2203 & $42.20^{\circ}$ & 0.2139 \\
\hline Heated up to $873 \mathrm{~K}$ & $40.68^{\circ}$ & 0.2216 & $41.88^{\circ}$ & 0.2155 \\
\hline
\end{tabular}




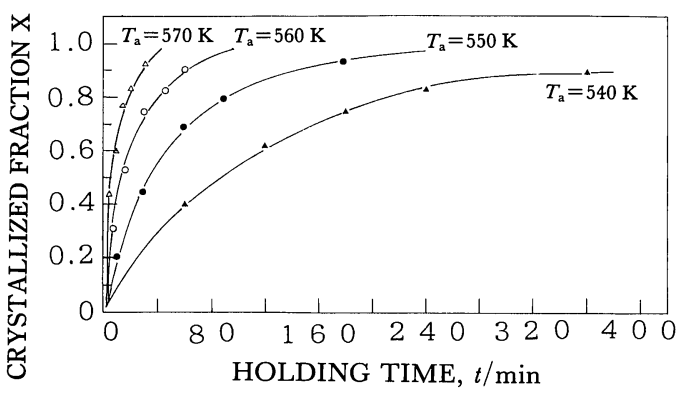

Fig. 5 Crystallization kinetics at different isothermal holding temperatures.

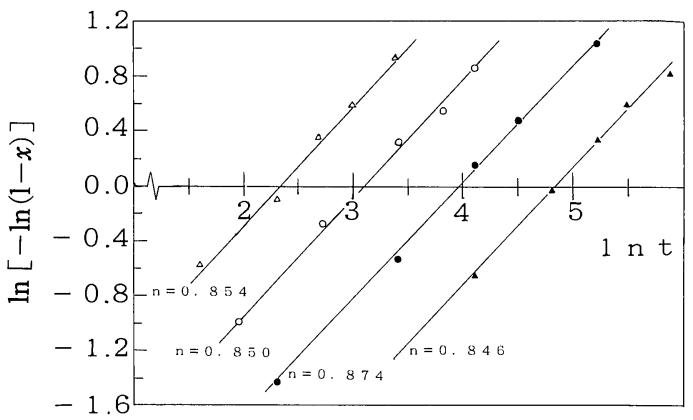

Fig. 6 Double logarithmic plot of crystallized fraction against $\operatorname{lnt}(t: \mathrm{min})$ at different isothermal holding temperatures: $\triangle 540 \mathrm{~K}, \bigcirc 550 \mathrm{~K}, \bigcirc 560 \mathrm{~K}, \triangle 570 \mathrm{~K}$ JMA index $n$ 's are given in Fig. 6 .

Table 3 Avrami exponent $n$ and logarithm of reaction rate constant $k$ at different isothermal holding temperaturres $T_{\mathrm{a}}$.

\begin{tabular}{c|c|c}
\hline \hline$T_{\mathrm{a}} / \mathrm{K}$ & $n$ & $\ln k$ \\
\hline 540 & 0.846 & -4.099 \\
550 & 0.874 & -3.472 \\
560 & 0.850 & -2.619 \\
570 & 0.854 & -1.983 \\
\hline
\end{tabular}

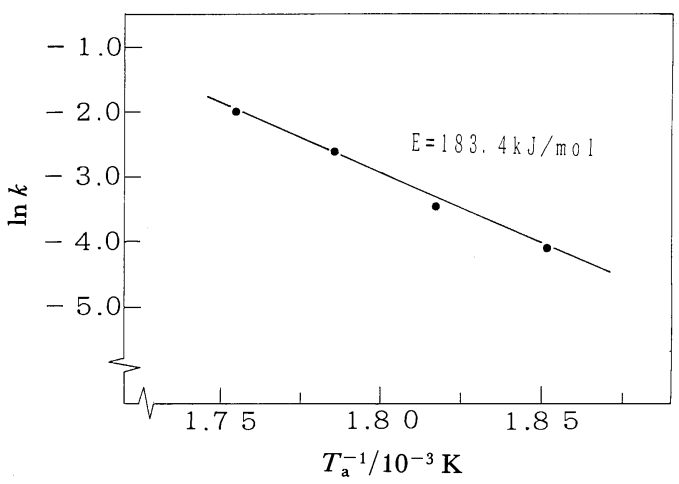

Fig. 7 Arrhenius plot of rate constant $k$ at different isothermal holding temperatures.
を示すことが知られている。ここで $k_{0}$ は定数， $E$ は活性 化エネルギー, $R$ は気体定数をそれぞれ表わす，等温保持 温度の逆数 $1 / T_{\mathrm{a}}$ に対して切片から得られた $\ln k$ をプロッ トした結果を Fig. 7 亿示す。傾きから得られた活性化工 ネルギーは $E=183.4 \mathrm{~kJ} / \mathrm{mol}$ と求まった.

\section{2. 連続昇温による結晶化}

次に連続昇温における非等温 kinetics を Kissinger 法を 用いて解析する。これは温度によらず一つの熱活性化過程 で結晶化が進行すると考えるもので，昇温中の各温度での 反応率を加算していくものである。

昇温速度 $\alpha$ の等速昇温で, 結晶化ピーク温度 $T_{\mathrm{x}}$ での反 応率が一定であるとすれば次式を得る。

$$
\ln \left(T_{\mathrm{x}}^{2} / \alpha\right)=E / R T_{\mathrm{x}}+\text { const. }
$$

$\alpha を 10,20,40 \mathrm{~K} / \mathrm{min}$ の 3 通りに変光た時の $T_{\mathrm{x}}$ の変化か ら活性化エネルギーEを求めると, Fig. 8 亿示したよう に $E=153.9 \mathrm{~kJ} / \mathrm{mol}$ を得た。これは等温解析から求まっ た活性化ェネルギーの值に近い.

式 (4) 温度 $T$ にお活る反応の進行が

$$
\begin{aligned}
& \frac{\mathrm{d} x}{\mathrm{~d} t}=C \exp (-E / R T) f(x) \\
& f(x)=(1-X)^{m}
\end{aligned}
$$

で表わされる反応について求まるものであり， $m=1$ の時 には式 (4)はピーク温度に㨟いての反応率 $x_{\mathrm{m}}$ が一定とい ら近似を含まないで成立する。

小沢 ${ }^{(8)}$ とよれば，反応を式(5)で表わした時に結晶化

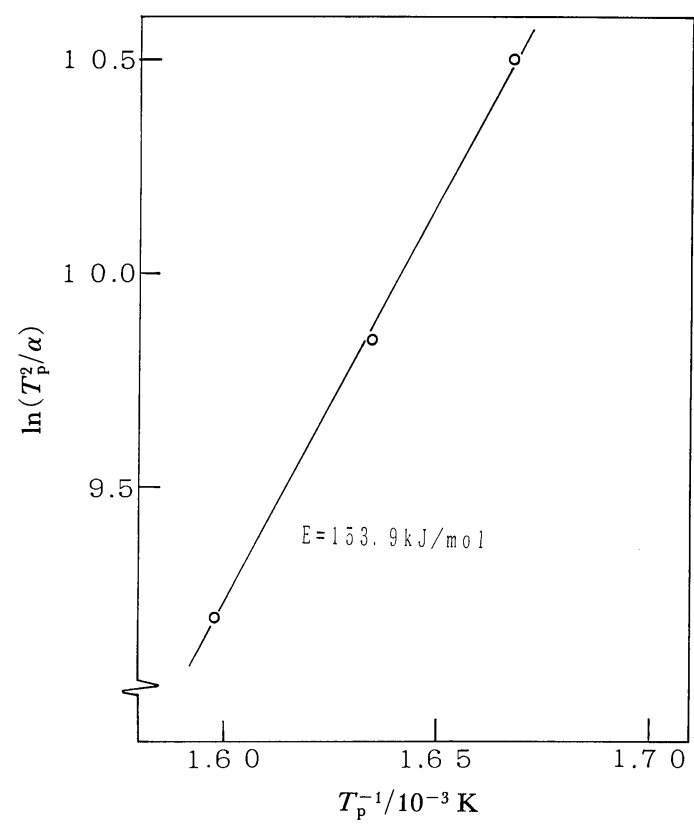

Fig. 8 Kissinger plot of crystallization peak temperatures at different heating rates. $T_{\mathrm{p}}$ in $K, \alpha$ in $\mathrm{K} / \mathrm{min}$. 
における結晶化ピーク温度までの結晶化率 $x_{\mathrm{m}}$ と反応次数 $m$ との間には

$$
1-x_{\mathrm{m}}=\left\{\begin{array}{l}
1 / e \quad(m=1) \\
(1 / m)^{1 /(m-1)} \quad(m \neq 1)
\end{array}\right.
$$

といら関係がある. 今回の場合得られた DSC 曲線 (Fig. 2)を用いてピーク全面積 $S$ に対するピーク点までの面積 $S_{\mathrm{x}}$ の比が

$$
x_{\mathrm{m}}=S_{\mathrm{x}} / S
$$

として式 $(7)$ を計算すると $m=1.0$ が得られた。

式 $(5)$ より 1 次反応の反応速度式は

$$
\begin{aligned}
& \frac{\mathrm{d} x}{\mathrm{~d} t}=C(1-x) \\
& C=C_{0} \exp (-E / R T)
\end{aligned}
$$

であり，等温といら仮定では $C=$ 定数となる．そこで等温 に拈ける結晶化の進行が式 (8)に従うとすれば, 式 (8) を積分することによって

$$
\ln (1-x)=-C t
$$

よって

$$
x=1-\exp (-C t)
$$

となり Avrami の指数として $n=1$ が得られる.

したがって等温結晶化の JMA の式による解析と連続昇 温結晶化の Kissinger の式による解析とは，1 次反応の場 合に一致する結果を与えることになり，今回の結果はこの 場合に相当する.

\section{N. 考察}

JMA の式における指数 $n$ は核生成および成長によって 異なり，

$n=1$ : 核生成速度が 0 , 拡散律速の 2 次元の結晶成 長

$n=1 / 2:$ 核生成速度が 0 , 拡散律速の 1 次元の結晶 成長

である ${ }^{(9)}$. 今回得られた $n \fallingdotseq 0.85$ に対しては，拡散律速 の 2 次元的な結晶成長の機構があてはまるものと考学ら れる.すなわち，この試料の結晶化では核生成サイトは飽 和され，2次元的な拡散による再配列のみが支配的である ことになる，従来，液体急冷法で作成された非晶質では JMA の式の指数 $n$ は一般に $2 \sim 4$ の值を示すことが多い. これは結晶の成長が 2 次元的よりも，より立体的である ことを意味している.今回 MG 法で作成した非晶質状態 との違いが結晶化過程においてあらわれていることが考え られる。金属間化合物から出発した MG 法で作成した非 晶質が結晶化に拈いて 2 次元的な成長を示すことは，残 存結晶を核として 2 次元的に成長することが考えられる.

求まった $\mathrm{Cu}_{50} \mathrm{Ti}_{50}$ の結晶化に打けるみかけの活性化 エネルギーを文献値と比較してみる. Hwangら ${ }^{(10)}$ は Kissinger 法により第 1 ピーク $\left(T_{\mathrm{x}}=691 \mathrm{~K}\right)$ で $305.6 \mathrm{~kJ} /$ $\mathrm{mol}$ ，第 2 ピーク $\left(T_{\mathrm{x}}=715 \mathrm{~K}\right)$ で $277.7 \mathrm{~kJ} / \mathrm{mol}$ を得てい
る. 速度定数 $k$ の温度依存性からは $331.8 \mathrm{~kJ} / \mathrm{mol}$ を得て いる。ただし結晶化機構については不明である。 Buschow ${ }^{(11)}$ にっても Kissinger 法により $272.9 \mathrm{~kJ} / \mathrm{mol}$ $\left(T_{\mathrm{x}}=701 \mathrm{~K}\right)$ が得られている.これらの值は我々の得た值 よりもかなり大きい.

その原因の一つは，急冷法で作成した試料の活性化エネ ルギーは核生成および結晶成長の両方の活性化エネルギー を含むものであると思われ，我々の得た值は結晶成長だけ を含むものであるからと思われる．Ranganathan ${ }^{(12)} に よ$ ると活性化ェネルギー $E$ と Avrami の指数 $n$ との間には 次の関係がある.

$$
\left\{\begin{array}{c}
\text { 界面に沏ける結晶成長 }: E=a E_{\mathrm{n}}+b E_{\mathrm{g}} \\
a+b=n \\
\text { 拡散律速による結晶成長 }: E=a E_{\mathrm{n}}+\frac{b}{2} E_{\mathrm{g}} \\
a+\frac{b}{2}=n
\end{array}\right.
$$

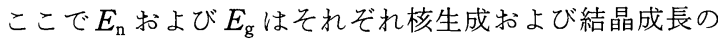
活性化エネルギー，パラメータ $a$ および $b$ は次のように 決められる。

$a=0 \quad:$ 核生成速度がゼロ
$a=1 \quad:$ 一定の核生成速度
$a>1 \quad:$ 核生成速度が増加する場合
$0<a<1:$ 核生成速度が減少する場合
$b=3 \quad: 3$ 次元の結晶成長
$b=2 \quad: 2$ 次元の結晶成長
$b=1 \quad: 1$ 次元の結晶成長.

すなわち，核生成が起こっているよらな結晶化では，核生 成の起こらない結晶化に比べて活性化ェネルギーは大きく なるのである.JMAの式による解析結果から考えると， $160 \mathrm{~h}$ ミリングした試料では $a=0, b=2$ があてはまるので $E \fallingdotseq E_{\mathrm{g}}$ となるはずであり，得られたみかけの活性化エネ ルギーの值が通常の拡散のそれに近いことから，JMAの 解析結果の信頼性が活性化エネルギーといら点から裏付け られたことになる。

次に結晶成長が拡散律速であるとして JMA の式から得 られるみかけの活性化エネルギー $E$ ，すなわち反応速度定 数の温度依存性から求まった活性化エネルギーからこの結 晶化に打壮る拡散の活性化エネルギー $E_{\mathrm{d}}$ を求めてみる.

JMA の式は反応生成物の体積 $V$ から次のように書け

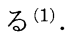

$$
X=1-\exp \left(-V_{\mathrm{ex}}\right)
$$

ここで， $V_{\mathrm{ex}}$ は拡張体積と呼ばれ変態終了体積を成長粒子 の重なりを重複を許して求めたものである．拡散律速の場 合は成長粒子の半径 $R$ は Zener の式(13)により

$$
R=A(D t)^{1 / 2}
$$

となる。ここで $A$ は定数， $D$ は拡散定数， $t$ は時間であ る。

よって 3 次元の場合 


$$
\begin{aligned}
V_{\text {ex }} & =\frac{4}{3} \pi R^{3} N \\
& =\frac{4}{3} \pi A^{3}(D t)^{1 / 2} N
\end{aligned}
$$

である．ここで $N$ は飽和核の数である.式(15)を式(13) に代入し，式 ( 1 ) と比較すれば,

$$
\begin{aligned}
k & =k_{0} \exp (-E / R T) \\
& =\frac{4}{3} \pi A^{3} D^{3 / 2} N \\
& =\frac{4}{3} \pi A^{3} D_{0}^{3 / 2} N \exp \left(-3 E_{\mathrm{d}} / 2 R T\right)
\end{aligned}
$$

を得る。ただし $n=3 / 2$ である。これより

$$
E=\frac{3}{2} E_{\mathrm{d}}
$$

となる。

反応生成物が球状でない場合についても同様に考えれば

$$
E=n E_{\mathrm{d}}
$$

である。この式 $(18) に E=183.4 \mathrm{~kJ} / \mathrm{mol}$ ，指数 $n$ として $n=0.85$ を代入して $E_{\mathrm{d}}=214.3 \mathrm{~kJ} / \mathrm{mol}$ を得る. 一方定数 表(14)によれば金属中の拡散の活性化エネルギーとして

$\mathrm{Ti}$ 中の $\mathrm{Cu}$ の拡散の活性化エネルギー：122 kJ/mol

$\mathrm{Cu}$ 中の $\mathrm{Ti}$ の拡散の活性化エネルギー：196 kJ/mol が得られている．上の文献值は純金属中の拡散を扱ったも のであり直接比較はできないものの, 求まった活性化ェネ ルギーは $\mathrm{Cu}$ 中の $\mathrm{Ti}$ の拡散のそれに近い.すなわち拡散 の遅いTi の拡散が律速となっていることが示唆される. また核生成は先に述べたように活性化エネルギーの大きさ から，結晶化の kineticsには寄与していないことが考光 られる。

JMA の式の指数 $n$ が 1 に近いことから残存結晶が結晶 化の核になる可能性があることを述べたが，ここで核の数 を推定してみる. 式 (16)の指数関数部分に対する係数か ら

$$
k_{0}=\frac{4}{3} \pi A^{3} D_{0}^{3 / 2} N
$$

が得られるのでこの式を用いて飽和核の数 $N$ を推定して みる.まず, $k_{0}$ は Fig. 7 において $\left(1 / T_{\mathrm{a}}\right)$ を 0 へ外挿する ことにより $\mathrm{Y}$ 切片から求められ， $k_{0}=1.52 \times 10^{14} \mathrm{~s}^{-1}$ であ る.

$A$ は例えば 1 次元成長の時は

$$
A=\frac{\left(n_{1}-n_{3}\right)}{\left[\left(n_{1}-n_{2}\right)\left(n_{3}-n_{2}\right)\right]}
$$

といら式(15)で与えられる。ここで $n_{1}, n_{2}, n_{3}$ はそれぞれ拡 散原子について, 結晶と非晶質との界面に打ける濃度, 初 晶結晶に打ける濃度, 非晶質部分での濃度である。この他 にも 3 次元の成長についても計算値が求まっている. こ れらの計算值 ${ }^{(15)(16)}$ によると $0<A<3$ 程度であることが わかっており，その多くはほぼ 1 に近い。そこで,ここ では $A=1$ として計算することにする.
$D_{0}$ に関しては金属中の值が報告されているが，活性化 エネルギーの違いから非晶質状態にそのまま使らことはで きない. 非晶質中の拡散係数 $D_{\mathrm{a}}$ と金属中の拡散係数 $D_{\mathrm{m}}$ との比較は報告 ${ }^{(13)(15)}$ によると $D_{\mathrm{a}}$ と $D_{\mathrm{m}}$ の大小関係は一 概には決定できないが，実測值的には

$$
10^{-1}<D_{\mathrm{a}} / D_{\mathrm{m}}<10
$$

の範囲にあると考えてもよい. いま, 純 $\mathrm{Cu}$ 中の $\mathrm{Ti}$ の拡 散 : $D_{0}=6.9 \times 10^{-5} \mathrm{~m}^{2} / \mathrm{s}, E=196 \mathrm{~kJ} / \mathrm{mol}$, および今回得 られた非晶質 $\mathrm{Cu}_{50} \mathrm{Ti}_{50}$ 中の $\mathrm{Ti}$ の拡散: $E_{\mathrm{d}}=214.3 \mathrm{~kJ} /$ $\mathrm{mol}$ を用いて $550 \mathrm{~K}$ に打ける非晶質での拡散係数の定数 部分 $D_{0}^{\mathrm{a}}$ を推定すると

$$
3.78 \times 10^{-4}<D_{0}^{\mathrm{a}}<3.78 \times 10^{-2} \mathrm{~m}^{2} / \mathrm{s}
$$

となる.ここで, 式(19)は 3 次元の成長について求めら れたものであるので，今回の結果に対しては 2 次元的な 成長をあてはめて考えることにする。この時, 式(19)は

$$
k_{0}=\pi A^{2} D_{0}^{\mathrm{a}} N
$$

といら形になる。この場合 $N$ は単位面積あたりの残存核 の数となる.これに $k_{0}$ の值と $A \fallingdotseq 1$ を代入して式 $(22) を$ 用いると

$$
1.28 \times 10^{15}<N<1.28 \times 10^{17} \mathrm{~m}^{-2}
$$

を得る。

$\mathrm{Lu} ら^{(17)}$ は液体急冷法で作成した非晶質 $\mathrm{Ni}_{80} \mathrm{P}_{20}$ に等温 保持による前処理を行なって結晶核を発生させ，処理後の 結晶核の数を SEM により直接数えている. それによると, $120 \mathrm{~min}$ の保持により $N=10^{16} \mathrm{~m}^{-3}$ 程度の結晶核が発生 したことを確認している。比較のために今回の結果を $N \fallingdotseq 10^{16} \mathrm{~m}^{-3}$ として単位体積あたりの核の数に直すと $N=\left(10^{16}\right)^{3 / 2}=10^{24} \mathrm{~m}^{-3}$ となりかなりの数の結晶核が残存 していたことがわかる.

$\mathrm{Lu} ら^{(17)}$ はこれと同時に結晶化ピーク温度 $T_{\mathrm{x}}$ と結晶核 の数 $N$ との関係を定量的に扱っている. 結晶化の機構を 前処理により発生した結晶核がそのまま核になり, 増加し ないでそのもとで結晶成長が起こるものと仮定し，JMA の式から次の関係式を導き出した。

$$
T_{\mathrm{x}}^{2} \exp \left(-E_{\mathrm{g}} / R T\right)=\frac{1}{N^{1 / 3}} \frac{\alpha E_{\mathrm{g}}}{0.985 R U_{0}}(4 \pi / 3)^{1 / 3}
$$

ここで $E_{\mathrm{g}}$ は結晶成長の活性化ェネルギー， $\alpha$ は昇温速 度, $U_{0}$ は定数で, 成長速度 $U$ に対して

$$
U=U_{0} \exp \left(-E_{\mathrm{g}} / R T\right)
$$

の形で定義される．実験方法としては，ある保持温度で保 持時間を変えて作った試料を冷却後, 昇温速度 $\alpha$ で昇温 しその時の $T_{\mathrm{x}}$ の変化を追うものである．式(25)によれば $N$ が増加するほど $T_{\mathrm{x}}$ は減少し，実際にそのような結果が 得られている.

今回の結果では保持時間に伴う $T_{\mathrm{x}}$ の減少はみられなか った。すなわち等温保持中に新たな結晶核の発生が起きて いなかったと考えられ，残存結晶核が核となり，結晶化が 成長律速であったといらことがここからも裏付けられる。

今回の解析では結晶化に拈いて核発生サイトが飽和され 
ているとして整理できた. MG 法で作成された試料では非 晶質化しなかった残存結晶質部分がこの飽和核となるとい ら考えを, 反応生成物が反応速度に影響を及ぼすといら自 己触媒反応の式で整理してみることにする．本来はこの自 己触媒反応といらのは，等温保持中によくみられる潜伏時 間中に核発生や構造変化が起こっているような反応につい てよく用いられ，また等温保持中の結晶化の時間進行が JMA の式に従わないような時(18)にも用いられている.

式(15)では反応速度が未反応率にのみ比例するとした のに対して，自己触媒反応は反応生成物にも比例して，そ の速度式は次のように書ける.

$$
\frac{\mathrm{d} x}{\mathrm{~d} t}=k^{\prime} x(1-x)
$$

これを積分して,$t=0$ で $x=x_{0}, t=t$ で $x=x$ とすれば

$$
\ln [x(1-x)]-\ln \left[x_{0} /\left(1-x_{0}\right)\right]=k^{\prime} t
$$

を得る. $\ln [x(1-x)]$ に対して保持時間 $t$ をプロットした 結果をFig. 9 に示した。この式の適合性として，Fig. 9 の直線性はTable 4 に示したよらに相関係数 $u$ が $u>0.96$ で良好である。特に保持温度が高温であるほどよ い結果が得られた。

反応速度定数 $K^{\prime}$ も Arrhenius 型の温度依存性を持つ。 $\ln K^{\prime}$ に対して $1 / T_{\mathrm{a}}$ をプロットした結果を Fig. 10 に示 した。傾きから求まる活性化ェネルギーは $E=219.7 \mathrm{~kJ} /$ mol となり，JMAの式によるみかけの活性化エネルギー から求めた拡散の活性化エネルギーと近いものが得られ た。

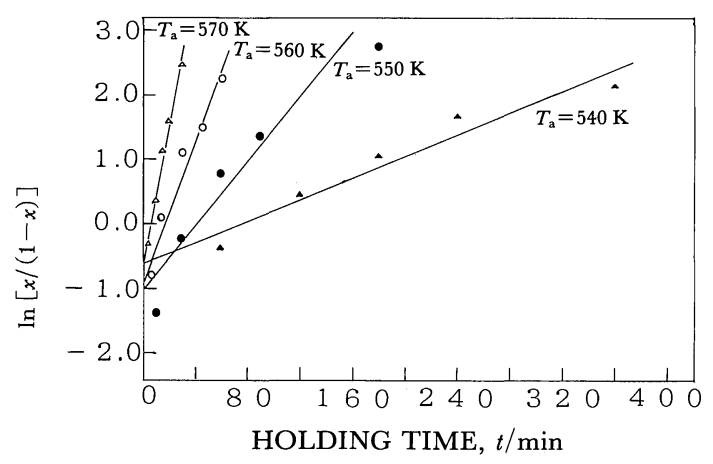

Fig. 9 Crystallization kinetics by Eq. (27).

Table 4 Corrrelation coefficients $u$, reaction rate constant $k^{\prime}, \ln \left[x_{0} /\left(1-x_{0}\right)\right]$, and $x_{0}$ at different isothermal holding temperatures $T_{\mathrm{a}}$.

\begin{tabular}{c|c|c|c|c}
\hline \hline$T_{\mathrm{a}} / \mathrm{K}$ & $u$ & $k^{\prime} / \mathrm{min}^{-1}$ & $\ln \left[x_{0} /\left(1-x_{0}\right)\right]$ & $x_{0}$ \\
\hline 540 & 0.962 & $8.32 \times 10^{-3}$ & -0.610 & 0.35 \\
550 & 0.968 & $2.26 \times 10^{-2}$ & -0.997 & 0.27 \\
560 & 0.977 & $5.46 \times 10^{-2}$ & -0.871 & 0.30 \\
570 & 0.991 & $1.09 \times 10^{-1}$ & -0.683 & 0.31 \\
\hline
\end{tabular}

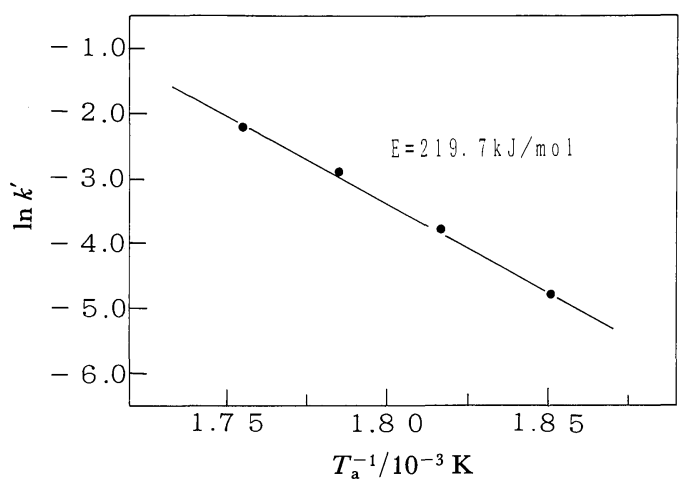

Fig. 10 Arrhenius plot of rate constant $k^{\prime}$ in Eq. (27).

ここで改めて式(1)抽よ゙式(27)について考えてみる. ともに等温保持中の結晶化の進行を整理する式であり, これら二つの式による解析結果は活性化エネルギーとして ほぼ一致する結果を与えたが基になる考え方は異なるもの である．比較のために式 $(1)$ の微分をとると

$$
\begin{aligned}
\frac{\mathrm{d} x}{\mathrm{~d} t} & =n k t^{n-1} \exp \left(-k t^{n}\right) \\
& =n k t^{n-1}(1-x)
\end{aligned}
$$

となる.ここで $n=1$ の時は $(8)$ の形になることは前に述 ベた．式(29)を $x$ を用いて書き直せば

$$
\frac{\mathrm{d} x}{\mathrm{~d} t}=n k^{1 / n}[-\ln (1-x)]^{(n-1) / n}(1-x)
$$

となり $n \neq 1$ に対しては $g(x) \equiv[-\ln (1-x)]^{(n-1) / n}$ の項が 効いてくる. 今回の $n=0.85$ に対しては $g(x)$ は $x$ の増加 に伴い単調に減少する。式(27)に拈いてはこの項は $x$ で 置き換わっている．結晶化の時間変化を追うという点にお いて式(1)抽び式(27)は独立な式である.しかし，そ れぞれの式で整理した結果, 実験結果に対する適合性はそ れぞれあるのでこの二つの式での整理を比較してみた.

Fig. 6 と Fig. 9 とを比較すると厳密な適合性については 直線性といら点について式（1）による解析のほうがよい.

式(27)のよい点は初期濃度すなわち残存結晶質の量を 算出できるといら点である。

Fig. 9 のを $t$ 亿外挿して切片から $\ln \left[x_{0} /\left(1-x_{0}\right)\right]$ を求 め, $x_{0}$ すなわち残存結晶質の割合を算出すると $x_{0} \fallingdotseq 0.31$ となった。 この $x_{0}$ は残存結晶質の単位体積率を表わすの でこの值から残存結晶質の数を求めてみる. $\mathrm{Cu}_{50} \mathrm{Ti}_{50}$ の結 晶構造は正方晶 $(a=0.3108 \mathrm{~nm}, c=0.5887 \mathrm{~nm})$ であり単位 体積あたりの残存結晶質を構成する単位胞の総数 $N^{\prime}$ は

$$
N^{\prime}=x_{0} /\left(a^{2} c\right)=5.45 \times 10^{27} \mathrm{~m}^{-3}
$$

となる。ここで先に求めた結晶核の数 $N$ とこの $N^{\prime}$ との 関係を考える．結晶核がいくつかの単位胞からなるクラス ターであるとすれば 1 個のクラスターを構成する単位胞 の数が求まる. $N=10^{24} \mathrm{~m}^{-3}$ とすれば 1 個のクラスターを 構成する単位胞の数は $N^{\prime} / N \fallingdotseq 10^{3}$ 程度であることがわか 
る.これは MG 法による非晶化はいくつかの単位胞から 成るかたまり，すなわちクラスターとして分解していき， 非晶質化していくということを示唆するものである。この クラスターの大きさがミリングに伴って小さくなり非晶質 化が進行するものと思われる.

またこのように作成した試料中で非晶質の部分と結晶質 の部分が混在していることは電子線回折像からも判明し た。

Fig. 11 はこの試料の電子線回折像を示した. (A), (B) ともに同一の試料から得られたものであるが，(A)のよう に非晶質の部分と(B)のように部分的に結晶質が残ってい る部分とが混在していることがわかった．MG 法で作成さ れた試料では，X 線回折では単一八ローパターンを示す 場合でもこのように試料内部での不均一性は否めないよう である.MG 法において非晶質化が残存結晶質部分がゼ口 まで進行するのか，もしくは非晶質化できる割合に限界が あるのかについては今後の研究課題である.

次に結晶化における Ti の拡散がどの範囲で起きている かを求めてみる。拡散距離 $r$ は

$$
r=(D t)^{1 / 2}
$$

から求まる。拡散係数 $D$ は

$$
D=D_{0} \exp (-E / R T)
$$

の形で書ける. 正確な $D$ の值がないので厳密な決定は不 可能であるが，大きさの推定はできる．先に述べたように
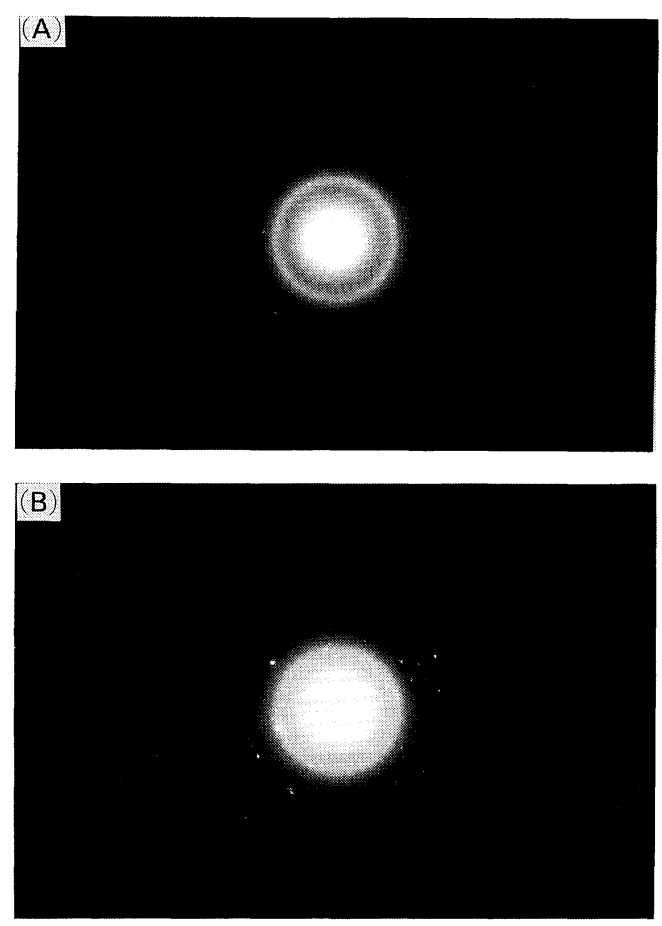

Fig. 11 Electron diffraction patterns of original specimen showing (A) amorphous (B) partially crystalline area.
非晶質中の拡散係数は金属中のそれと大きさはほぼ等しく, $D=10^{-20} \mathrm{~m}^{2} / \mathrm{s}$ 程度と考えてよい，例えば $T_{\mathrm{a}}=550 \mathrm{~K} に$ おいては結晶化率 $x=0.5$ まで $t=2.4 \mathrm{ks}, x=0.95$ まで $t=12 \mathrm{ks}$ であるので，それぞれ拡散距離を求めると

$$
\begin{aligned}
& x=0.5 ; r=4.9 \mathrm{~nm} \\
& x=0.95 ; r=11.0 \mathrm{~nm}
\end{aligned}
$$

となる. $\mathrm{Cu}_{50} \mathrm{Ti}_{50}$ の結晶構造は先に述べたように正方晶 $(a=0.3108 \mathrm{~nm}, c=0.5887 \mathrm{~nm})$ であり，ここから考えられ るのは結晶化に伴ら拡散は短距離であることであり， 600 $\mathrm{K}$ 前後の低温，そして短時間で結晶化が終了することを 考えると，非晶質の結晶化はこのよらな短範囲に拈ける再 配列ではないかと思われる。初期に执いては拡散により再 配列が起き，構造緩和が結晶化を律速するというような機 構が考えられる。

\section{V. 結 論}

$\mathrm{Cu}_{50} \mathrm{Ti}_{50}$ 金属間化合物結晶粉末を高エネルギーボールミ ルで粉砕 (MG 法) し, 非晶質状態を得た。この試料を結晶 化ピーク温度以下での等温保持および連続昇温によって結 晶化しその kinetics を調べた。

(1) 等温保持中の結晶化の進行はJohnson-MehlAvrami の式でよく整理される. 指数 $n$ は0.85で急冷法で 作成した非晶質の結晶化に和ける值よりも小さく，2 次元 的な結晶成長を伴らことが示された。 またみかけの活性化 エネルギーは $183 \mathrm{~kJ} / \mathrm{mol}$ で急冷材の場合よりも小さい.

結晶の 2 次元的な成長が拡散によるとして拡散の活性 化エネルギーに換算すると $214 \mathrm{~kJ} / \mathrm{mol}$ となり，金属 $\mathrm{Ti}$ 中の $\mathrm{Cu}$ の拡散の活性化エネルギー $122 \mathrm{~kJ} / \mathrm{mol}$, 金属 $\mathrm{Cu}$ 中の $\mathrm{Ti}$ の拡散の活性化エネルギー $196 \mathrm{~kJ} / \mathrm{mol}$ より大き い值が得られた。

さらに結晶核の数を推定し $10^{24} \mathrm{~m}^{-3}$ を得た。これは急 冷材 $\mathrm{Ni}_{80} \mathrm{P}_{20}$ の築温保持に抢ける結晶核の実測値 $10^{16} \mathrm{~m}^{-3}$ に比べて大きい.

(2) 連続昇温における結晶化の kineticsを Kissingerの 式で解析した。この場合の活性化ェネルギーは $154 \mathrm{~kJ} /$ mol で等温保持の kineticsに抢ける結果に近い.JMAの 式に拈ける指数 $n$ が 1 に近いために対応関係がよいもの と考えられる.

（3）結晶化の核が MG 法における残存結晶であると仮 定し, 自己触媒反応，すなわち反応速度が未反応量と反応 生成物量の両者に比例するとして解析した結果は活性化エ ネルギーは $220 \mathrm{~kJ} / \mathrm{mol}$ で, JMA の式から求めた拡散の 活性化エネルギーにほぼ一致する。またこの解析から残存 結晶質の比率を求めると0.31であり, 結晶核の大きさは $10^{3}$ 単位胞程度と考えられる.

（4）非晶質中の拡散係数が結晶金属中の拡散係数と同じ 桁であるとすれば, 結晶化温度における拡散距離は 5 $10 \mathrm{~nm}$ できわめて短範囲の原子の移動で結晶化が起こる 
と考えられる.

(5) MG 法で作成された試料では X 線回折でハローパ ターンを示し，DSCで結晶化の単一ピークを示す場合で も結晶相が残存することは電子顕微鏡における電子回折か らも確かめられた。

（6）以上の結果から，金属中化合物のメカニカルグライ ディングによる非晶質状態は結晶質が残存しそれを核とし て結晶化が進行すると考えられる.

\section{文献}

(1) M. Avrami: J. Chem. Phys., 7 (1939), 1103.

(2) E. G. Baburaj, G. K. Dey and R. Krishnan: Scr. Metall., 19 (1985), 305.

( 3 ) C. F. Conde, H. Miranda, A. Conde and R. Marquez: J. Mater. Sci., 24(1989), 139.

(4) C. O. Kim, T. K. Kim and M. Takahashi: Proc. 4th Int. Conf. on Rapidly Quenched Metals, The Japan Inst. Metals, (1982), 723.

( 5 ) C. H. Hwang, Y. J. Ryeom and K. Cho: J. LessComm. Met., 86(1982), 187.

(6) R. B. Schwarz and R. R. Petrich: J. Less-Comm. Met., 140 (1988), 171.
（7）中村邦康，笠井清史，南雲道彦：日本金属学会春期 講演概要, (1990), 366.

( 8 ) T. Ozawa: J. Thermal. Anal., 2 (1970), 301.

(9) J. W. Christian: The Theory of Transformation in Metals and Alloys, 2nd Edn, Pergamon, London, (1975).

(10) C. H. Hwang, K. Cho and K. Kawamura: Rapidly Quenched Metals, Elsevier Science Publishers B. V., (1985), 331.

(11) K. H. J. Buschow: Script. Met., 17 (1983), 1135.

(12) S. Ranganathan and M. V. Heimendahl: J. Mater. Sci., 16 (1981), 2401.

(13) B. Cantor: Proc. 5th Int. Conf. on Rapidly Quenched Metals, Germany, Elsevier Science Publishers B. V., (1984).

（14）日本金属学会 ; 金属データブック改訂 2 版, 丸善, (1984).

(15) C. F. Chang and J. Marti: J. Mater. Sci., 18(1983), 2297.

(16) L. E. Collins, N. J. Grant and J. B. Vander Sande: J. Mater. Sci., 19(1983), 804.

(17) K. Lu and J. T. Wang: Mater. Sci. Eng., 97 (1988), 399.

(18) N. Funakosi, T. Kanamori and T. Manabe: Japn. J. Appl. Phys., 17 (1978), 11.

(19) C. Politis and W. L. Johnson: J. Appl. Phys., $60(1986), 1147$. 